\title{
Evaluation of Cash Management at Kirupalaya Trust Villupuram
}

\author{
P.Tamilselvan, Gowtham Aashirvad, Anitha K
}

\begin{abstract}
The present project study is on "An Analysis of Cash Management at Kirupalaya Trust, Villupuram". This study highlights the concepts of cash management, its components and the trend in the cash management based on past five years data. This study also points out the problem faced by the company in maintaining a proper cash management level.

This study is about the cash management in Krupalaya Trust, made for certain period only i.e. 2013 - 2017. To know the sources of Cash inflow and uses of cash outflow in the company. To determine how Short-Term obligations of the Company are met by the Liquidity Ratio and Short-Term Solvency Position and the trend. Through this study the financial results of the company were analysed in different accepts, from that the assessment of the cash management of company is made several issues regarding the cash management was monitored and the cause and effect of the study concludes that the overall cash position of the company is better. The company's overall position is at a good position.
\end{abstract}

\section{INTRODUCTION}

Now a days Cash management of a concern is a difficult task. Proper and efficient cash management only matches inflow of cash and outflow of cash. Finance manager of a concern needs to concentrate on effective utilization of a raised cash in order to avoid financial deficit. [1], [3], [5]

Hence in this project I have chosen the topic, "An Analysis of Cash Management at Krupalaya Trust Villupuram". In this study, I have taken the past five years income statement and balance sheet to study the cash management in the trust. The study focuses how effectively the Krupalaya trust manages its cash flow in order to reduce excess outflow of cash and retain the cash in the trust[2 ],[4],[6]

Revised Manuscript Received on July 22, 2019.

P.Tamilselvan Department of MBA,Bharath institute of Higher Education \& Research,Tamilnadu,India Email: ptamilselvan@gmail.com

Gowtham Aashirvad, Assistant Professor, Department of MBA,Bharath institute of Higher Education \& Research,Tamilnadu,India Email: rajmohanravimohan@gmail.com

Anitha.K, Department of Civil Engg,Bharath institute of Higher Education \& Research,Tamilnadu,IndiaEmail: anithakrish26@yahoo.co.in

\section{DATA ANALYSIS AND INTERPRETATION}

\begin{tabular}{|c|c|c|c|}
\hline \multicolumn{3}{|c|}{ TABLE NO. 1 } \\
\hline \multicolumn{3}{|c|}{ CASH TURNOVER RATIO } \\
\hline Year & Sales & Cash & Ratio \\
\hline 2013 & 604325 & 60926.00 & 9.91 \\
\hline 2014 & 1771672 & 227720.50 & 7.78 \\
\hline 2015 & 339250 & 1000.00 & 339.25 \\
\hline 2016 & 1326130 & 1000.00 & 1326.13 \\
\hline 2017 & 4524286.95 & 289859.45 & 15.61 \\
\hline
\end{tabular}

\section{Interpretation}

The above table shows that the cash turnover ratio is 9.91 in the year of 2013. It has decreased to 7.78 in the year of 2014. It has increased to 339.25 and 1326.13 in the year of 2015 and 2016 respectively. It has decreased to 15.61 in the year of 2017 [31],[33]

\section{RESULTS}

Money turnover proportion has expanded to 339.25 and 1326.13 in the time of 2015 and 2016 individually. It has diminished to 15.61 in the time of 2017 . Money to current resources proportion has expanded to 1.00 in the time of 2014. It has additionally expanded to 2 in the time of 2015 . Regulatory costs proportion has diminished to 4.27 and expanded to 25.02 in the time of 2015 and 2016 individually. It has again diminished to 16.11 in the time of 2017. Profit for absolute resources has expanded to 0.95 in the time of 2014. It has additionally expanded to 1 and diminished to 0.16 in the time of 2015 and 2016 individually. Fixed resources turnover proportion has diminished to 13.29 in the time of 2014. Resources turnover proportion has expanded to 678.50 and expanded to 1326.13 in the year of 2015 and 2016 individually. It has again diminished to 15.61 in the time of 2017. Current advantages for all out resources proportion has expanded to 1 and stay for the following two successive years. Capital turnover proportion is 9.35 in the time of 2013. It has diminished to 4.91 in the time of 2014. Intrigue inclusion proportion has diminished to 0 and further diminished to 0.33 in the year of 2015 and 2016 individually. It has again expanded to 7.31 in the time of 2017. The capital store is 18371 in the time of 2013. It has expanded to 361020.50 in the time of 2014. The loan bosses is Rs. 50500 in the time of 2013. It has paid by the worry. Thus it has demonstrated nil balance in the following four continuous years. The lenders are Rs. 50500 in the time of 2013. It has paid by the worry. Subsequently it has demonstrated nil balance in the following four

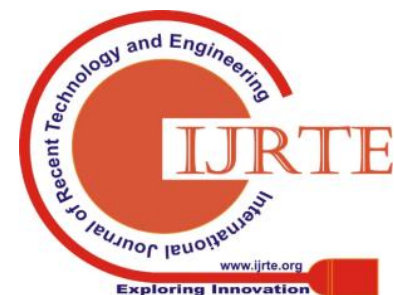




\section{Evaluation of Cash Management at Kirupalaya Trust Villupuram}

back to back years. Managerial receipts have diminished to Rs. 0 and further expanded to Rs. 471 in the time of 2015 and 2016 separately. It has additionally expanded to Rs. 39527 in the time of 2017. [7], [9] ,[11]

The terrific receipts for govt. plans has diminished to Rs. 1504172 in the time of 2014. There is no any terrific receipts for govt. plans for the following two successive years. The pattern rate has diminished to 0.14 in the time of 2015 . It is shortfall in the time of 2016 and there is 84.30 as pattern rate in the time of 2016 and 20017 separately. The pattern level of commitment receipts. There is 100 as pattern rate in the time of 2013. [8],[ 10], [12]

The money turnover proportion and profit for all out resources has vacillation in the five succeeding years. There is no fixed resources turnover proportion over the most recent three years. The present resources for complete resources proportion has the dependability over the most recent three years[13], [15], [17]

\section{CONCLUSION}

The cash management is very faulty as a result of which cash ratio to total current assets and to sales is very high for the trust. With the above general observations, one can draw number of conclusion about the economic health of the trust and various aspects. The trust at present is depend on the sources of funds from local contributions, administrative receipts and grant from govt. schemes. This state of the trust is expected to continue in near future, the trust should fin few alternatives for its sources of funds. This would increase its life of the trust. [14],[ 16], [18]

From the critical analysis, it shows a clear picture about the cash management throughout the study. It is evident that the overall cash management of the trust with regard to matching of inflow of cash and outflow of cash is not satisfactory but still, the trust can be maximizing through stringent measures which enhances the operating of the company. [25],[27],[29]

Through this study the financial results of the trust were analyzed in different adepts, from that the assessment of the cash management of trust is made several issues regarding the cash management was monitored and the cause and effect of the study concludes that the overall cash position of the trust is better. Since the trust faces less receipts and fixed assets in certain years, the management has to take several steps in order to improve the receipts and payment[19],[21],[23]

\section{REFERENCES}

1) BharthVajan R., Ramachandran S.,Psychographic dimensions of training,2016,International Journal of Pharmacy and Technology,V-8,I-4,P-23727-23729

2) Balakrishnan P., Bharthvajan R.,A study on human resource planning in hospitals in Chennai City,2014,International Journal of Applied Engineering Research,V-9,I-22,P-7503-7507

3) Priyadarsini P., Bharthvajan R.,Role of emotional intelligence training programme in reducing the stress of the nurses,2014,International Journal of Applied Engineering Research,V-9,I-22,P-7411-7421

4) Kerinab Beenu G., Bharthvajan R.,Empirical analysis on the cosmetic buying behavior of young women in South India,2014,International Journal of Applied Engineering Research,V-9,I-22,P-7361-7366

5) Balakrishnan P., Bharthvajan R.,Whistling in the wind,2014,International Journal of Applied Engineering Research,V-9,I-22,P-7586-7593
6) Krishnan B., Peter M.,Health hazards of Indian Bpo employee-an alarming issue,2014,International Journal of Applied Engineering Research,V-9,I-22,P-7336-7341

7) Kerinab Beenu G.H., Peter M.,Role of insurance in economic development,2014,International Journal of Applied Engineering Research,V-9,I-22,P-7532-7539

8) Balakrishnan P., Peter M., Priyadarsini P.,Efficiency of safety measures for wellbeing of employees in manufacturing industry,2014,International Journal of Applied Engineering Research,V-9,I-22,P-7376-7382

9) Anbarasi M., Praveen Kumar S.,Online sales promotions of herbal products and its effectiveness towards tanisha.com,2019,Indian Journal of Public Health Research and Development,V-10,I-1,P-195-200

10) Anbarasi M., Praveen Kumar S.,Various online marketing and promotions strategies to improve the validation towards the organic products in the pharmaceutical sectors,2019,Indian Journal of Public Health Research and Development,V-10,I-1,P-263-269

11) Loganathan R., Praveen Kumar S.,Grievance handling a key factor for solving issues of employees in an organization,2014,International Journal of Applied Engineering Research,V-9,I-22,P-7483-7491

12) Loganathan R., Praveen Kumar S.,Study on preference of private label brands in super and Hypermarkets,2014,International Journal of Applied Engineering Research,V-9,I-22,P-7327-7335

13) Smitha M., Praveen Kumar S.,Understanding stress and its managementamong the nurses in Chennai city,2014,International Journal of Applied Engineering Research,V-9,I-22,P-7560-7565

14) Kerinab Beenu G.H., Praveen Kumar S.,A study on the investment behavior of Chennai investors in mutual fund schemes,2014,International Journal of Applied Engineering Research,V-9,I-22,P-7520-7525

15) Loganathan R., Praveen Kumar S.,Retention strategies key for organizational productivity,2014,International Journal of Applied Engineering Research,V-9,I-22,P-7443-7447

16) Pavithra J., Ganesan M., Brindha G.,State wise analysis of microfinance sector in India,2016,International Journal of Pharmacy and Technology,V-8,I-4,P-23417-23432

17) Pavithra J., Ganesan M.,A comparative study on microfinance in India and abroad,2016,International Journal of Applied Business and Economic Research,V-14,I-8,P-5471-5476

18) Pavithra J., Ganesan M.,A study on awareness and impact of micro-financial schemes,2016,International Journal of Applied Business and Economic Research,V-14,I-8,P-5449-5460

19) Senthilmurugan P., Pavithra J.,Consumer preference towards organised retailing with reference to Big Bazaar,2014,International Journal of Applied Engineering Research,V-9,I-22,P-7469-7475

20) Senthilmurugan P., Pavithra J.,Implication of social media marketing in growing healthcare industry,2014,International Journal of Applied Engineering Research,V-9,I-22,P-7448-7456

21) Loganathan R., Pavithra J.,Consumer perception towards private label brand over other brands in super markets and hypermarkets,2014,International Journal of Applied Engineering Research,V-9,I-22,P-7355-7360

22) Kerinab Beenu G., Pavithra J.,Tradeâ€"off between liquidity and profitability in logistics industry,2014,International Journal of Applied Engineering Research,V-9,I-22,P-7398-7401

23) Kerinab Beenu G., Pavithra J.,A study on the prospective consumerâ€(M perception towards utility cars in Chennai city,2014,International Journal of Applied Engineering Research,V-9,I-22,P-7526-7531

24) Pavithra J., Dilli Babu P., Ambuli T.V.,A study on budgetary control at Maruti Service Masters, Chennai,2014,International Journal of Applied Business and Economic Research,V-12,I-2,P-151-161

25) Pavithra J., Dilli Babu P., Ambuli T.V.,A study on customer satisfaction of retro Garments Pvt Ltd, Chennai,2014,International Journal of Applied Business and Economic Research,V-12,I-2,P-381-391

26) Kerinab Beenu G.H., Pavithra J., Senthilmurugan P.,A study on the influence of promotional activities for TATA ARIA among consumers in Chennai,2014,International Journal of Applied Engineering Research,V-9,I-22,P-7572-7578

27) Vijayaragavan S.P.,An investigative expert that's general FBG sensors,International Journal of Mechanical Engineering and Technology,V-8,I-8,PP-1500-1505,Y-2017

28) Vijayaragavan S.P.,Equalization routing protocol for Wi-Fi sensor strategy,International Journal of Mechanical Engineering and Technology,V-8,I-8,PP-1662-1666,Y-2017

29) Karthik B., Kiran Kumar T.V.U., Vijayaragavan P., Bharath Kumaran E.,Design of a digital PLL using 0.35 $\hat{\mathrm{I}}^{1} / 4 \mathrm{~m}$ CMOS technology,Middle East Journal of Scientific Research,V-18,I-12,PP-1803-1806,Y-2013

30) Kanniga E., Selvaramarathnam K., Sundararajan M.,Kandigital bike operating system,Middle - East Journal of Scientific Research, V

31) Jasmin M., Vigneshwaran T., Beulah Hemalatha S.,Design of power aware on chip embedded

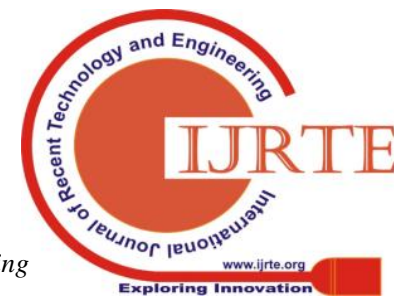


memory based FSM encoding in FPGA,International Journal of Applied Engineering Research,V-10,I-2,PP-4487-4496,Y-2015

32) Jasmin M.,Optimization techniques for low power VLSI circuits,Middle East Journal of Scientific Research,V-20,I-9,PP-1082-1087,Y-2014

33) Jasmin M., Vigneswaran T.,Fuzzy controller for error control of on - Chip communication,2017 International Conference on Algorithms, Methodology, Models and Applications in Emerging Technologies, ICAMMAET 2017,V-2017-January,I-,PP-1-5,Y-2017

\section{AUTHORS PROFILE}

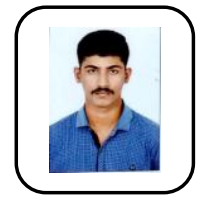

P.Tamilselvan Department of MBA,Bharath institute of Higher Education \& Research,Tamilnadu,India Email: ptamilselvan@gmail.com

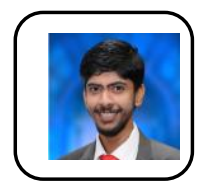

Gowtham Aashirvad, Assistant Professor, Department of MBA,Bharath institute of Higher Education \& Research,Tamilnadu,India

Anitha.K, Assistant ProfessorDepartment of Civil Engg,Bharath institute of Higher Education \& Research,Tamilnadu,India 